Housing Studies

\title{
From informal housing to apartment housing: exploring the 'new social' in a gecekondu rehousing project, Turkey
}

\section{Tahire Erman}

To cite this article: Tahire Erman (2018): From informal housing to apartment housing: exploring the 'new social' in a gecekondu rehousing project, Turkey, Housing Studies, DOI: 10.1080/02673037.2018.1458293

To link to this article: https://doi.org/10.1080/02673037.2018.1458293

\section{曲 Published online: 01 May 2018.}

Submit your article to this journal $\sqsubset$

Џ Article views: 125

View Crossmark data $\longleftarrow$ 


\title{
From informal housing to apartment housing: exploring the 'new social' in a gecekondu rehousing project, Turkey
}

\author{
Tahire Erman \\ Department of Political Science and Public Administration, Bilkent University, Ankara, Turkey
}

\begin{abstract}
This article engages with the question of the 'new social' that emerges in the relocation of the poor in slum renewal projects. Drawing upon both Lefebvre's theorization of abstract space of capital and social space of people, and the neoliberal framework in which the economic dominates the social, the complex relationship between the spatial and the social embedded in political economy is demonstrated. In the Turkish context, the 'new social' is situated at the intersection of spatial transformations, housing representations, neoliberalism and Islam. In the housing estate of the case study, the abstract space was challenged by the bottom-up responses of some residents who tried to create their social space rooted in their previous experiences in the gecekondu; it was reacted by other residents who embraced the higher status of apartment living. The void produced by destroying the gecekondu habitus was filled by religious activities and consumption-inspired everyday practices.
\end{abstract}

\section{ARTICLE HISTORY}

Received 10 July 2016

Accepted 5 March 2018

\section{KEYWORDS}

Urban renewal projects; social space/abstract space; neoliberalism; gecekondu rehousing projects; Islam; Turkey

\section{Introduction}

This paper aims to contribute to the discussion of urban renewal projects ${ }^{1}$ by exploring the 'new social' in the lives of people relocated to apartments upon the demolition of their houses for 'redevelopment.' In Turkey as elsewhere in the global South, informal housing ${ }^{2}$ originally built by occupants faces mass demolition in 'neoliberal redevelopment policies' (Doshi, 2013, p. 846). Urban land has turned into a highly demanded commodity, and in the market logic of local governments, land in informal settlements has become a valuable asset for 'the proliferation of new land markets and lucrative redevelopment opportunities' (Doshi, 2013, p. 847).

The focus in the literature on urban renewal projects as the means of intervention into the housing of the poor for rent appropriation has left understudied the experiences of the people rehoused in the estates built by the state. In a large-scale urban renewal project implemented in the West End of Boston in the late 1950s, the working-class population experienced grief in relocation when they were moved from their residential area where they shared a common identity and culture (Fried, 1963). In this paper, it is suggested that the grief caused by leaving behind their familiar residential area and neighbours may be 
accompanied by problems caused by moving to a housing estate designed by professionals. The tension inherent in the production of space from above is well theorized by Henri Lefebvre (Lefebvre, 1991). The few studies on relocation in urban renewal projects in recent times demonstrate the dialectical relationship between residents' agency in their everyday practices of reappropriation of spaces in their new housing (Lefebvre's 'social space') and the restrictions imposed on their behaviour by authorities who design and manage the housing estates (Lefebvre's 'abstract space'). For example, in a slum upgrading project in Recife-Brazil, residents actively transformed the places in the estate to make them respond to their needs; this frustrated architects and project administrators, who stigmatized the estate as the 'new favela' (Koster \& Nuijten, 2012). In an urban transformation project in Istanbul-Turkey, in its goal of 'civilizing' the people from informal housing, the management company attempted to regulate strictly residents' behaviour inside the housing estate, creating a 'sense of captivity' (Bartu-Candan \& Kolluoğlu, 2008). Although these studies tell us about the contestations between residents and authorities in urban renewal projects, we need a deeper understanding of the new lives of people when they are relocated to a radically different environment, designed and managed formally. This is important because it will inform us about the consequences of the new approaches to informal housing in the neoliberal turn that are driven by a market-driven logic, and illuminate the changes in the lives of the urban poor, which may affect their social support networks. A new type of relations with neighbours and the built environment may emerge as the result of the state's intervention into the residential areas of the poor. As Ghannam (2002) has demonstrated, residents' interaction with each other became formal and distanced as they were relocated from their neighbourhood in central Cairo to the modern apartments built by the state.

In the goal to explore social transformation in urban renewal projects, this paper draws on Lefebvre's theorization of abstract space-social space and Harvey's critical framework of neoliberalism. The 'new social' is coined in the article, which was inspired by the idea that the economic dominates the social in neoliberalism (Harvey, 2005), and the abstract space of capitalism dominates the social space of people (Lefebvre, 1991). Thus, the 'new social' refers both to the production of space (i.e. abstract space) and the new economic order (i.e. neoliberalism). It is specifically defined as the phenomenon that emerges via the production of housing by the state that is radically different from the previous housing of residents, both in physical features and management; it is governed by a neoliberal logic and contextualized in rising Islam in Turkey. Using ethnographic data, the new social is investigated as grounded in residents' everyday experiences. The article is limited to the discussion of the abstract space of Karacaören-TOKI (hereafter K-TOKI), which largely consists of high-rise apartment blocks that are designed in accordance with the norms of the urban middle classes, is managed by a formal system of rules, and built by a neoliberal logic without any care for responding to residents' needs and preferences. The following research questions frame the article. Firstly, how did moving to a radically different built environment, namely, from low-rise single-family houses to high-rise apartment blocks, affect neighbourly interaction? Secondly, how did moving from informal housing to a housing project regulated by rules affect everyday life behaviour? Thirdly, how did moving from a gecekondu area (i.e. squatter housing in Turkey) associated with rurality to an apartment project associated with urbanity affect self-identification and social relations? And fourthly and lastly, how did the incorporation into the mortgage system via monthly payments for apartment ownership and the increased expenses in apartments affect sociability? 
Before moving to discuss the 'new social', the case study is introduced, followed by background information about the changing approaches to informal housing in two periods guided by different political economies.

\section{The case study: a gecekondu rehousing project in Northern Ankara}

An ethnographic study was carried out for 44 months (April 2010-December 2013) with those who were relocated in a housing estate following the demolition of their houses in the Northern Ankara Urban Transformation Project (NAUTP). The project was carried out by the partnership of the Ankara metropolitan municipality and TOKI (Toplu Konut $\dot{\mathrm{I}}$ daresi - Housing Development Administration of Turkey) in the northern periphery of Ankara, during which some 7000 gecekondus were demolished. This intervention was justified by the mayor using the discourse of the need to 'develop' the area through which the highway to the international airport passed so that the gecekondus would not be a disgrace to the capital on its way to becoming a 'world city.' In his attempt to appeal to gecekondu residents in his populist politics, the mayor also used the discourse of providing better housing for gecekondu families. In the treatment of land as currency, 'rightful owners' (those with title deeds) would exchange their land with an apartment, paying the difference if their land was smaller than the designated size and the municipality paying the difference if it was larger. With a mentality that the project costs should not consume the state's resources, it was planned as a 'cross-financing' project in which the sale of luxurious housing (called 'financing housing' in the project) would subsidize the construction of housing for the gecekondu population. ${ }^{3}$ In the concern of making the most profit from the project by responding to class distinction, the rightful owners' housing would be separated by a road from the financing housing. Being the first large-scale urban transformation project and the prestige project of the mayor, NAUTP had something to offer also to those without title deeds: they would get an apartment in the housing estate to be built by TOKI in a distant location (K-TOKI) on the condition that they agreed to pay monthly mortgage instalments for 15 years. The project was implemented in a rush after a special law was passed in the parliament in 2005. To make the demolition process free of potential opposition, the mayor offered free stay in the municipality housing served with 24 -h hot water during the waiting period. The construction of K-TOKI was completed in 2008. Today it has a population of 20.000 , and it contains 12-storey apartment blocks (19 in number) and 15-storey apartment blocks (20 in number), along with apartment houses of 3-stories (42 in number) which were scattered within the estate. The project had four housing stages: the first three stages were inhabited by the relocated gecekondu population, and the 4 th stage was built by TOKI for those who would purchase apartments at subsidized lower rates on the open market (about 1000 families/5.000 persons); as told by management officials, TOKI personnel owned some of the apartments in this housing stage, which they rented out. As part of the project, TOKI also built a shopping mall, a mosque, a school building and a health centre.

In the field study, in-depth interviews were conducted with K-TOKI residents in two intervals (60 and 55, respectively: 35 women and 25 men; 35 women and 20 men). They were complemented by questionnaires implemented again in two intervals (220 and 215, respectively). Residents were visited in their homes; some residents (mostly men) were also

interviewed at the shopping mall. The fact that some of the residents were contacted during the previous research in 2007 when they lived in the municipality housing increased the 
chance for interviewing. To find about the changes people experienced as they established their lives in the new housing environment, the time dimension was brought into the study. For the interviews, residents were chosen both by availability and contribution to the theoretical question. Two criteria guided the selection of respondents. Firstly, those who differed in terms of their location and housing type, and secondly, those who carried the potential for the researcher to follow up the themes that emerged during the in-depth interviews of previous respondents were targeted. In the theoretical interest in the neighbourliness in the new housing, one block was focused towards the end of the research, during which several households were visited many times. The second round of interviews with those who participated in the first round of interviews created the opportunity to engage more deeply in the issues of the research project. The data were analysed qualitatively, looking for the emerging themes. For the questionnaires, respondents were selected by quota random sampling using the estate's map; the selection criteria included on what floor, in what type of housing (low-rise/high-rise), and in what location inside the housing estate (e.g. close to/distant from the main entrance of the estate) they lived. The questionnaires aimed to find out the representativeness of the themes that emerged in the in-depth interviews. The data were analysed by the SPSS program. In addition to residents, the muhtar (the elected head of a neighbourhood) and the shopkeepers at the shopping centre were interviewed about their views of the place and the people. ${ }^{4}$ In the spring of 2016 and 2017, the estate was visited ten times as part of a graduate course, during which visits were paid to several women who were former respondents, as well as to the new muhtar.

\section{Engagements with informal housing in the global south}

In the national developmentalist era (1950-1980) in the global South, in which states prioritized industrialization over social welfare, squatter houses mushroomed in their megacities whose inhabitants provided cheap labour for thriving manufacturing industries. Called by supranational organizations such as the United Nations and the World Bank as 'self-help housing,' they were seen as the solution to the housing problem of poor migrants who were displaced by the mechanization of agriculture. Self-help housing was celebrated for its potential to respond both to the economic conditions of the poor by its flexible construction (one room built first, new rooms added as some capital was accumulated) and to their cultural values by allowing them to build their own houses as they wished (Turner, 1976), as well as for lifting from the state the financial burden of providing housing for the economically disadvantaged (Pugh, 2000). In the Turkish case, gecekondus met with state tolerance in populist politics that targeted the votes of rural migrants in the city, who outnumbered established urbanites (Danielson \& Keleş, 1985). Under such approach, squatter houses with higher physical quality compared to those in other countries were built, and squatter settlements with basic infrastructure and municipal services developed (Neuwirth, 2006).

In the political economy of the neoliberal age, informal housing in the global South is demolished en masse to release the 'rent gap' (Smith, 1987), entailing the mass displacement of the urban poor (Lelandais, 2014; Roy, 2009) and their dispossession ('capital accumulation by dispossession' (Harvey, 2003)). In urban renewal projects implemented with a neoliberal logic, slum dwellers may be incorporated into the scheme of homeownership with state-subsidized mortgage loans (Salcedo, 2010), yet this may create financial burden on dwellers with limited financial capacities (Erman, 2016). Such projects may work to the benefit of slum dwellers if the state intervenes to make the project attractive to private 
developers (Nijman, 2008) or to act as the primary source of funding in its implementation when the property values are high (Mukhija, 2003). Yet, the misfit between the designed environment and the residents' way of life (Bartu-Candan \& Kolluoğlu, 2008; Koster \& Nuijten, 2012), or the stigmatization of the subsidized housing project (Salcedo, 2010) may cause problems. In the politics of compensation, slum dwellers may engage in negotiations with developers for shares from profit (Doshi, 2013); Roy (2009) defines it as 'differentiated inclusion' due to the state's double practice of inclusion and exclusion (i.e. using a set of criteria such as the year of the construction of the house, the state decides to include some slum dwellers and to exclude others in urban renewal projects). Bringing advantages to some and disadvantages to others, the displacement compensation approach challenges the homogeneous view of slum dwellers as victims. Yet, it causes the breakdown in social bonds among slum dwellers.

Through new legislation and institutions, or the restructuring of old ones such as TOKI in the 2000s, the Turkish state has increased its power in appropriating land for value extraction, which facilitated its intervention into the sites of the urban poor (Kuyucu \& Ünsal, 2010). In the 'zero gecekondu' politics of the municipal governments, gecekondus are increasingly demolished and replaced by apartment blocks either via urban transformation projects (UTPs) or by private developers. In UTPs, people are moved from their gecekondus and rehoused in apartment blocks built by TOKI - the state's neoliberal tool in the housing market (Kuyucu \& Ünsal, 2010). In this model of gecekondu transformation, the state serves as the means of capital accumulation rather than the means of modernizing 'rural masses' living in gecekondu areas (Erman, 2014). The physical transformation of gecekondu housing via UTPs is carried out by a neoliberal logic that aims for the expansion of financial and housing markets (Bartu-Candan \& Kolluoğlu, 2008; Karaman, 2008; Kuyucu \& Ünsal, 2010): gecekondu dwellers are incorporated into the financial system via mortgage loans and their land into the formal housing market via apartment blocks. This fits well with the responsibilization of the poor in 'market-embedded mentality' (Shamir, 2008), and with the goal of 'the extension of mortgage finance to groups who previously had little access to credit' (Jones, 2012, p. 777). In this spatial politics, the Justice and Development Party (Adalet ve Kalkınma Partisi, hereafter AKP), which has been in office since 2002, has been successful in blending neoliberal logic with Islam, consolidating its power by creating a growing number of private developers who make profit from urban restructuring and support the ruling party both by their votes and by their donations to Islamic foundations (Karaman, 2013) and, in veiled ways, to municipal governments (Buğra \& Keyder, 2006).

The move from single-family houses to high-rise blocks in UTPs is promoted by the trope of apartment living (Erman \& Hatiboğlu, 2017). Mayors present their projects using the discourse of giving the poor the chance of reaching better living conditions in apartments. The image of apartments as the place of the urban middle classes (Erman, 1997; Kiray, 1979), which continues its hegemony in society despite the fact that it is challenged today by the move of middle and upper-middle classes to suburbs, and apartment living as a status symbol for rural migrants (Ayata, 1989; Erman, 1997), appeal to those gecekondu residents who carry the desire for social mobility. In the following, the question of the social in the gecekondu is discussed, and without overlooking the presence of those gecekondu residents who are not happy with the gecekondu life, it dwells on the normative gecekondu sociability of intimate neighbourly relations and mutual help. This is followed by the new social in the apartment estate, discussing its accommodation and contestation by different groups. 


\section{The sense of community and sociability in the social space of the gecekondu}

Gecekondu life is characterized by informality in neighbourly relations, which are close and dense; they are not regulated by arrangements made in advance (Erman, 1996). The physical features of gecekondu neighbourhoods support such sociability: the semi-public/ semi-private spaces around the houses provide the opportunity for informal gatherings, and as such they accord with Newman's idea of 'defensible space' (1972). Social networks in the local space and trust in the local people, who are in some cases migrants from the same village/town sharing the same ethnic or sectarian identity (Seufert, 1997), create a sense of community and support gecekondu residents in coping with the challenges inflicted from city life (Seufert, 1997; Suzuki, 1964). In sum, a social support system that grew from poor people's dependency on each other in their daily survival in the city inscribes itself in the gecekondu context.

Cooperation is likely to arise when economically disadvantaged and socially excluded groups share the same housing, which is observed, for example, in a public housing project in Chicago in which neighbours created networks of mutual help and support (Manzo et al., 2008). This support system among neighbours in the housing environments of the poor gains a deeper meaning in the gecekondu context because of its embeddedness in the experience of producing their place collectively 'in the face of a hostile officialdom' (Keyder, 2000, p. 122): they help each other to build their houses; they go to the municipality as a group to make demands for infrastructure and municipal services; and they resist collectively the attempts of the municipal police to demolish their houses (Erman, 2011). In the field study, a woman told about how the destruction of her house by the municipality's demolition team was prevented when her neighbour advised her to give a fake image of a newborn baby sleeping in the bed using a pillow. Over the years, gecekondu solidarity has been challenged by individualistic motives of social mobility and material gains of younger generations. In their quest for some autonomy, especially young women tend to complain about the social control by their neighbours and would be willing to move to an apartment district (Erman, 1997).

In the gecekondu area in the case study located far from the city centre, multiple dependencies among neighbours prevailed, ranging from mutual support to daily socializing. Especially women who lived in closed communities were dependent on each other in their everyday lives. Many were housewives, and limited family budget as well as conservative social norms kept them inside the neighbourhood. They usually formed small groups in which they developed intimate relations of sharing and support. More than half of the respondents told that they kept their house doors unlocked during the daytime in their gecekondu lives so that they could visit each other without any formality, expressed in the following quotation: 'I would kick the door and enter my neighbors' houses, saying, "hi Ayşe, hi Fatma, I am here." They would often have their breakfast or lunch together; and they would do some house chores collectively, ranging from stuffing grape leaves for special occasions such as weddings, to baking bread (thin and round sheets of dough baked on fire) in large quantities for the winter. Quotations are given below to demonstrate the collective nature of social relations and sharing among neighbours:

Sharing is nice. If you have two, you give one of them to your neighbor. [...] We would prepare our trays and take them to each other's houses to have breakfast together. If we did not see each other for a couple of hours, we would stop by to see if everything was okay; 
'I used to grow vegetables and herbs in my garden. When I made bazlama (flat bread) filled with herbs from my garden, I would shout out for my neighbors', 'Nursel, Aynur, come, I made bazlama, let's eat together'; 'We would do everything together. We would carry the coal sacks to each other's storage spaces. We would make bread together, we would prepare stripped pasta together. Whatever we did, we would do it together. I miss those days.' Fadime (42) described her experience of making bread with her neighbours as fun:

We would come together with neighbors in the outdoor houses to bake bread. We would start right after we sent our children to school and end late at night. One day for me, one day for another neighbor, we would take turns. We would sing and tease each other while making bread.

This intimacy and sharing in neighbourly relations were not limited to women. Men also formed close relations with their neighbours: 'I would never have my tea without my neighbors. I would invite people passing by, "Mehmet, Ahmet, come in, let's have tea"; 'My nextdoor neighbors would come every evening; we would play cards, drinking tea. It was so much fun.' In these conservative families, such intimacy was legitimized by defining the husband of the other family as brother and the wife as sister: 'We were just like sisters. Our husbands and us (the wives), we were all like siblings'; 'The two families, we were like one household.' They would feel responsible for their neighbours' children, even punishing them if they felt necessary. This would not bother the parents since they regarded their neighbours as family. When an elderly couple and their previous neighbour from the gecekondu (Yayla, a middle-aged woman) met at the pastry shop inside the estate's shopping mall, they told the story of Yayla telling the husband of the couple to go to her bedroom and take the money from the bedside table when he asked for money to borrow. They laughed, admiring the trust they had in each other in their gecekondu lives.

When some families moved out and newcomers moved in, the norm of mutual help and cooperation that regulated social behaviour in the gecekondu was passed over to newcomers. This is not to deny the fact that there were arguments among neighbours, but in their commitment to their intimate neighbourly relations, they would develop tactics to solve neighbourly disputes. Nigar (40) narrated a particular practice in her group of neighbours:

There was a big rock close to our houses. We (neighbors) called it our family house. We would gather there, chatting and having fun in the company of each other. Those who had a fight with their neighbors would return from the visit to the rock, leaving behind their dispute.

The social control over local people by women sitting outdoors is another feature of gecekondu life (Erman, 1998). Interestingly, in the field study respondents did not mention this aspect when they were asked about their gecekondu lives, with a few exceptions. ${ }^{5}$ For example, Emir (46), who worked in a middle-class district, said: 'I don't like to have strong ties with my neighbourhood, I care for my freedom. In the gecekondu, you feel like everybody is keeping an eye on you.'

The social in the gecekondu was challenged upon the move to the apartment, presented below.

\section{The new social in the abstract space of the apartment}

Lefebvre formulated a tripartite production of space, namely, the representation of space, which is tied to the relations of production and capital accumulation, and refers to the 
Table 1. Responses to 'neighborliness' in the questionnaire.

\begin{tabular}{lcc}
\hline Questionnaire & 1st round (\%) & 2nd round (\%) \\
\hline Preference for neighbourly relations in the gecekondu & 86.1 & 83.4 \\
Preference for neighbourly relations in the apartment & 13.9 & 16.6 \\
Close neighbourly relations very important & 95.5 & 91.2 \\
\hline
\end{tabular}

production of space by planners and private developers (the conceived/abstract space); representational space, which refers to space as lived through its associated images and symbols (the lived space); and spatial practices, which refer to people's skills of using space (the perceived space) (Lefebvre, 1991). K-TOKI can be understood using this framework. The search for profit played a role in the design and location of K-TOKI: in the goal of producing many units fast, which fits with the neoliberal logic, TOKI used a standard apartment plan which was originally designed for urban middle-class families; and to save from land in search for profit, high-rise blocks came to be the main building type. This built environment conflicted with the spatial experiences of residents in their representational space in the gecekondu.

The nature of social interaction in the gecekondu changed by the move to the apartment. Three major dimensions are identified to discuss it: firstly, the design of the new housing as high-rise apartment blocks (i.e. the physical aspect), secondly, the meaning of apartment life in Turkish modernity (i.e. the social aspect), and thirdly, the increased expenses and mortgage payments in apartment life (i.e. the economic aspect). They lay the ground for privatized lives and formalized social relations, and trigger 'contentious neighborliness,' elaborated below.

\section{Privatized lives and formalized social relations?}

The production of space in K-TOKI by professionals via the design of apartments prescribed a new sociability rooted in formalized social relations and privatized lives, which was imposed in a top down fashion onto residents. By defining sharply the boundaries between the public and private space, the apartment door signified formality; it became the symbolic barrier that kept non-family members out. This was alien to former gecekondu dwellers. The introduction of rules of social behaviour by the management office was also alien to them. They gained some power in shaping their environment when the management company linked to TOKI had to move out upon residents' opposition, and block managers, who were elected by residents living in the same block, came to fulfil this role.

A major theme that emerged in the interviews was respondents' strong preference for the neighbourliness in the gecekondu (see Table 1). When residents were interviewed in the early stage of their move, many respondents (45/60), ages ranging from 28 to 60, said that they missed their gecekondu lives, which was supported by the responses in the questionnaire (see Table 2). The changing nature of neighbourliness was one of the main reasons: 'I cannot enter my neighbor's apartment freely. I have to ring the bell first and wait for her to open it. She may not open. It is so stressful'; 'In the gecekondu, we were close to each other. When we got out, we would see each other. Our windows and doors faced each other's. Here you close your door and you don't seen anyone. Neighborly relations are cold'; 'Only a couple of neighbors visited me when my mother passed away. Fifty, sixty people, maybe the whole neighborhood would have come if I had been living in the gecekondu. No caring 
Table 2. Responses to 'gecekondu vs. apartment' in the questionnaire.

\begin{tabular}{lcc}
\hline Questionnaire & 1st round (\%) & 2nd round (\%) \\
\hline Missed gecekondu life very much & 53.6 & 52.3 \\
Would definitely go back to gecekondu if it were possible & 53.2 & 48.4 \\
Apartment life more expensive & 81.7 & 74.2 \\
Economic problems increased in apartment life & 74.3 & 49.3 \\
\hline
\end{tabular}

for others here.' Another reason was the increased expenses in apartment life (see Table 2). In the second round of interviews, the feeling of longing for their lives in the gecekondu continued (46/55).

The abstract space of the housing estate was reappropriated in the course of time by those who longed for the gecekondu sociability and activities. Familiarizing themselves with their new environment, they began to transform the estate via their spatial practices; this was so especially when women started using the estate's public spaces for informal social gatherings and domestic tasks. The economic burden of mortgage loans and apartment expenses also played a role in the informalization of neighbourliness; as families tried to economize, they developed a reserved attitude towards the social gatherings at home that expected them to serve several refreshments, as practiced by their middle-class counterparts. Akkız, who had the desire for upward mobility, put it as follows: 'I cannot invite my neighbors to my place; it is too expensive.' Moreover, it led to the individualization of the social in some families when family members, including women and youth, started spending (more) time working and cared more for their economic survival/advancement in their apartment lives than for their neighbourly relations. It caused complaints: 'After people moved here, they became stingy; no sharing anymore.' On the other hand, some women, who were used to the idea of a vague boundary between the public and private space, and favoured informality in social relations, challenged the formal neighbourly interaction prescribed by abstract space. As they got to know their neighbours, usually limited to those living one floor up and down and/or across the hall, they started forming their small groups of neighbours in which they practiced their old habit of visiting each other without a notice in advance, asking from each other favours and engaging in everyday exchanges of food, which signified intimate neighbourliness. They also came up with new means of contacting their neighbours, narrated by Ayfer (49):

No arrangements are made in advance here to meet neighbors. In the summer, we ring each other's bells, telling that we will be sitting outside waiting for them. In a nutshell, we have formatted this place into a gecekondu. (almost nine years after their move)

Women started gathering in the spaces in front of their blocks with their neighbours, just like in the gecekondu: 'I don't feel lonely here. We sit outdoors until dark. Look, we are all in gecekondu clothes.' Being visible outdoors enabled informal gatherings: women seeing others sitting outside would join them. These gatherings worked beyond mere socialization; taking their chores outside (fluffing mattress wool, trimming vegetables, and the like), women could reach other women who would come down from their apartments to help them, replicating the way some domestic tasks were done collectively in the gecekondu. In the second round of interviews, they said they started doing this kind of activities more easily as time progressed (32/34) (see Table 3). The imam (the official head of a mosque) supported women's outdoor gatherings: 'This is good. It allows women to continue their relations with their neighbors.' He continued: 'Yet those who come from outside feel strange 
Table 3. Responses to 'activities restricted in the housing estate.'

\begin{tabular}{lcc}
\hline Questionnaire & 1st round (\%) & 2nd round (\%) \\
\hline Very restricted & 23.9 & 16.7 \\
Somewhat restricted & 26.1 & 17.2 \\
Not restricted at all & 50.0 & 66.0 \\
\hline
\end{tabular}

when they see it in the apartment context.' As the imam's comment illustrates, these transformations in the use of space led to contestation over what a 'proper behavior' should be in the apartment estate, discussed below.

\section{Contentious neighbourliness}

One theme that emerged regarding 'contentious neighborliness' was about the desire of some residents for social mobility via apartment living, confronting those who kept their orientation to the gecekondu. Mostly younger women and men under the influence of modernity objected, in their own words, to 'the transformation of the estate into a gecekondu site'; they associated it with the cultural backwardness and ignorance of their neighbours (the 'peasants in the city' argument in the literature, for example, Mangin (1970)), which is situated in the rural-urban dichotomy in Turkish modernization. They blamed their neighbours for failing to adapt to their new housing and remaining ignorant of the rules of apartment living. Murat, a man of 46 who grew up in the city, criticized women's gathering in front of the blocks: 'I am against such things. Not a nice view. They look at people, talking behind. They are those with rural culture.' Songül, a woman of 29 whose wish was to live in an apartment in a middle-class neighbourhood, criticized the transformation of the estate into a gecekondu setting: 'The apartment environment should be modern, but here it is like gecekondus placed on top of each other. Women's outdoor socialization brought back the social control of the gecekondu, affecting especially young women. Funda (20) complained about it: 'Out there women gather in the summer. They talk behind me when I go out. It gets on my nerves. In the gecekondu, there was sincerity, I liked it. But here people do not trust each other.'

The emergence of new social meanings of neighbourliness intensified the confrontation between the supporters of a gecekondu way of life and those who opposed to it. Under the influence of the prestige of apartment life for rural migrants (Ayata, 1989), especially young women started adopting middle class values that prioritized the nuclear family over the community, which is celebrated by neoliberalism for 'retreat(ing) into a private sphere where people seem concerned only with self and immediate family' (Layton, 2014, p. 468). Zehra (32) put it as follows:

I cannot spend my time with neighbors. I have responsibilities for my family. I cannot go to my neighbors all the time. I want to be at home when my children come back from school. I have to devote my time to my children and my husband.

As some residents changed their approach to their neighbours, it caused complaints in others: 'After they moved to apartments, they started behaving as though they created the world. They are so conceited'; 'Some women pretend that they have become ladies. We all came from the village, yet when we moved to top places (i.e. high-rises), they thought they were ladies.' Residents were divided around the question of what kind of people should live 
in the apartment: while some said that anyone could live in the apartment (33/60), others said that this should not be the case, as expressed in this quotation: 'Not anyone can live in the apartment. They came from the gecekondu, and they bake bread inside their apartments, they sit in front of the blocks. They are transforming the estate into a gecekondu area.' Accordingly, K-TOKI turned into a contested environment, both spatially and socially.

One other theme that emerged in the interviews was residents' commitment to pay monthly mortgage instalments ${ }^{6}$; they were ready to make sacrifices: 'Do not let the boat sink. Apartment installments are our priority. We'll stop eating, we'll stop sending our children to school. What else can we do?' The maintenance of apartment blocks in formal ways, for which monthly fees had to be collected from each household, created another source of contestation, especially under the conditions of increased expenses in apartment living; residents started blaming each other for causing the deterioration of their building by not paying maintenance fees. Here again the discourse of those residents who were aware of the importance of paying maintenance fees against those 'ignorant' residents who lacked such awareness was at the core of the contestation.

The physical proximity in high-rise blocks was another cause of 'contentious neighborliness.' Objects thrown from upper floors were a major source of complaint: 'My neighbors throw down cigarette butts, they shake table cloths from windows'; 'My neighbor on the 9th floor leaves her wet carpet hanging down from the balcony, water dripping on my table in the balcony. It caused sanitation concerns when garbage was thrown down from balconies, which decreased in number over the years. As residents spent more time in their apartments, the stigma of 'improper behavior' of those who failed to educate themselves about the rules of apartment living developed, creating a social hierarchy among residents. Another source of complaint regarding physical proximity was the noise coming from neighbours: 'The noise from my neighbor living upstairs is driving me crazy. She has two young kids. I complained to the block manager but he did nothing about it. Why is he the manager then? He has to warn the neighbor.' Living too close in apartment blocks started fights, especially during the initial stage of the move to apartments; the story of a man who ran up to his neighbour upstairs with a knife in his hand spread among neighbours. Although such behaviour showed a tendency to decrease in the course of time as people adapted to their new lives, the stigmatization process continued, some blaming others for being unfit for apartment life.

The following sections move beyond the new social in the home environment to include broader forces that played a role in constituting the 'new social.'

\section{The 'new social' in the housing estate}

In the housing estate, two major forces are identified with which residents negotiated in the production of the new social. One of them is religion. In Turkey since the AKP's coming to power in the 2002 elections, and increasingly since 2007 when the party consolidated its political and economic power, Islam has been a major constitutive element of society, leading to sociocultural and political polarization as 'secularists' vs. 'Islamists.' AKP's Islamist base is made up mostly of conservative people from Anatolian towns and migrants from the countryside living in gecekondu neighbourhoods in big cities (Tuğal, 2009), which includes the ones in the NAUTP. Yet, while Islamist activists played a leading role in the formation of some gecekondu settlements such as Sultanbeyli in Istanbul (Tuğal, 2009), 
in the gecekondu areas demolished by the NAUTP, people built their houses without any connections to Islamists. And the second force constituting the new social in the housing estate is related to consumerism grounded in the experiences of residents in the local shopping mall. Following the introduction of neoliberal policies since the 1980s and in its more aggressive form since the 2000s during the rule of the AKP (Kuyucu \& Ünsal, 2010), participation in consumerist society has been the norm that included those with limited economic capacities. The following sections elaborate on the two forces in constituting the new social.

\section{Islam in the new social: the production of an Islamic habitus}

The support given to AKP in this housing estate ${ }^{7}$ because of the trust in the party leader's representation of the values and interests of the lower conservative classes has clouded the fact that their houses were demolished and they were burdened with new economic challenges during the rule of this party. Putting the blame on the mayor who initiated the project, they 'whitened' the AKP. ${ }^{8}$ This paved the path to the production of an Islamic habitus in the estate.

The presence of religious orders (tarikat) was noticeable in this estate located in the larger district known for its Islamist identity (Pursaklar). Tarikats and dervish houses of the Ottoman Empire were closed down in 1925 following the founding of the Turkish Republic built upon the tenet of secularism. Yet, they went underground and kept their negotiations with political parties, coming out to support Islamist parties [National Salvation Party (1972-1980), Welfare Party (1983-1997), Virtue Party (1997-2001), and Felicity Party (2001-)] and going underground in times of radical secularization (e.g. after the February 281997 event). They have been encroaching into the neighbourhoods of the poor after the 1980 coup d'état that attempted to redesign Turkey in accordance with the ideology of the Turkish-Islamic synthesis. They have extended their activities after the Islamist AKP came to power, which, in its victory in three consecutive elections, gained control of society. The informal presence of tarikats in gecekondu neighbourhoods repeated itself in this estate; the mosque administration rejected any connection to the tarikats functioning inside the estate. A branch of the Naqshbandi tarikat was particularly active: disguising tarikat identity, they organized a fund-raising event under the banner of a mutual assistance and solidarity association, calling it 'charity kermis', and by the money collected, they were planning to buy an apartment in the estate, which reveals their intention of permanent presence. At the time, they were renting two apartments (which they called 'dergah') in the estate, one for women and one for men; in the women's apartment, they offered kindergarten services, which were very cheap compared to others in the district; some rooms were reserved to store second-hand clothing to be distributed to the needy who attended the meetings. A young woman said:

There are about thirty women at the meetings. It gets more crowded on special days. They organize ravioli (mant) days; women gather and make mantı, bringing them to apartments to sell. They pay utility bills by this money. They make loafs of bread and sell them; they also sell clothes.

Especially women whose mobility was largely restricted to their residential environment and who were stressed by the mortgage loan payments were attracted to them. Akkiz 
(29), one of the key informants who desired to form contacts with the modern educated classes and wanted to get middle-school and high-school diplomas by attending open education after her children grew up, started attending religious meetings when her wish to get a job as a cleaner or babysitter could not come true. Such meetings served various functions in the lives of women, ranging from pragmatic functions of solving daily problems to providing the chance to socialize, and to find relief from daily troubles, which increased when they were brought under the regime of mortgage payments and the discipline of apartment life. During the meetings, social networks were formed that benefitted the attendees, such as the provision of jobs for family members and access to social aid.

Women's increasing integration to Islamic activities affected neighbourly socialization: they would gather in each other's apartments for Quran talks (Kuran sohbetleri). Even 'gold days,' which were the recent version of middle-class women's neighborliness, and were emulated by lower income women as a means of saving money (a predetermined amount is given to the woman hosting the meeting), contained some Quran recitation. Several women in the interviews mentioned the solemn atmosphere it brought to neighbourly meetings: 'Before we would chat, laugh and even dance. Now we listen carefully the Quran reading.' Not all religious meetings were quiet; because of the noise made when the $z i \mathrm{kir}^{9}$ was performed in some meetings, and additionally due to political motives, some residents would object to them. In addition to informal religious activities, the mosque built by TOKI as part of the project offered Quran courses for women, and during the summer time, for children. Families liked to send their children to the Quran courses both for religious and pragmatic reasons: in this estate distant from the city centre and with limited social facilities, Quran courses provided space for children to spend their free time while they were incorporated into Islam smoothly. ${ }^{10}$ Under the influence of Islamic groups and activities, teenage girls practiced hijab at a younger age (11 or 12), which is harshly criticized by those who adhere to the secular tenets of the Republic.

In this habitus of Sunni Islam (see Table 4), veiled women dominated the public spaces of the estate, those with their hair uncovered - a few modern Sunni and many Alevi ${ }^{11}$ women - becoming a minority. In their religious beliefs and political views, Alevi women would not practice the hijab, which would cause their exclusion by their Sunni neighbours; they would also become the target of Islamists, who would invite them to Quran recitations at homes, pressuring them to cover their hair and body. In sum, the imposition of Islam via Sunni tarikats and the increasing role of religion in everyday life created the conditions of exclusion for those who did not observe the rules of Islam. Although this 'new social' rooted in Sunni Islam was contested to some degree, the small number of Alevis and secular families in the estate, as well as the rising Islam in the wider society under the AKP rule did not leave them much space to resist.

Table 4. Responses to 'living in a religious environment.'

\begin{tabular}{lcc}
\hline Questionnaire & 1st round (\%) & 2nd round (\%) \\
\hline Very important & 61.5 & 49.8 \\
Somewhat important & 31.7 & 46.0 \\
Not important & 6.8 & 4.2 \\
\hline
\end{tabular}




\section{Consumerism in the new social: the shopping mall as the place of socialization and consumption}

In the design of the housing estate, the 'shopping mall' was located at the main entrance across the mosque. It brought new opportunities to socialize and new habits of consumption promoted by the higher status of apartment living. With its stores ranging from the butcher's to the stationery, from the pastry shop to the tailor's shop, from the postal office to the natural gas payment point, along with its three chain and two local supermarkets whose stands spreading out into the mall's public spaces, it was nothing like a conventional shopping mall. Since there were no places inside the estate for people to spend their free time and socialize, the 'shopping mall' became the substitute: women would come in groups to check the discount campaigns of the supermarkets; elderly men would extend their time in the mosque to the mall, strolling in its public spaces; teenage boys, many of whom were school dropouts, would stand in groups in and around the mall. Although some women were not allowed by their husbands to visit the mall because of the 'strangers' there, others would come to mix with the crowd. In the words of a middle-aged woman whose grown-up children had moved out after they got married: 'It is fun to be here. I am bored sitting alone in my apartment. I come here to see people, to get involved in events.' During the research, these events ranged from the fund-raising of a tarikat under the banner of a mutual assistance and solidarity association, to a free eye examination of a private eye clinic recently opened in the larger district.

Despite the popularity of the mall as the only public space of socialization, there were no seats inside the building, diverging from a typical shopping mall. The public toilets were locked to prevent mall visitors from using them, which implied that they were ignorant people who did not know how to use a toilet properly. The only places to sit were the pastry shop on the ground floor and the shop specialized in grill chicken on the lower floor: one would see both men and women, although the latter were few, sitting at tables by themselves or in small groups, tasting new (and cheap) food that they could not cook at home, and so developing new habits and learning new ways of being a customer. The lack of sitting space inside the mall was compensated to some degree by the owner of the pastry shop, who allowed people to use its chairs without ordering anything.

The shopping mall was the context in which the former gecekondu population was stigmatized for their cultural and economic 'deficiencies.' Many shopkeepers had negative views of their customers, looking down upon them as uncultured people from the gecekondu who did not know how to behave in a shopping mall: as they told in the interviews, people would come into the stores, walking around and leaving without buying anything; they would bargain aggressively despite the fact that the prices were already very low; they would try to return the goods they bought after using them or tearing their packages, etcetera, etcetera. In a nutshell, they referred to them as 'deficient' customers. But shopkeepers also felt the need to be in good terms with the people because of the fact that they were their potential customers on which their businesses depended. The problems in the mall extended beyond the complaints of shopkeepers. As observed, parents would shout at their children when they asked for a new toy or clothing, and children would scream to make their parents buy them, causing a big noise in the mall. There were also complaints about children's using the escalator as a playground despite the fact that the mall management had placed warnings on the walls, prohibiting such behaviour. Moreover, women's long skirts, 
which were common attire in this conservative estate, would cause problems while women were using the escalator, humiliating them.

In brief, the shopping mall came to be a strong component of the new social that was formed beyond the home environment. As people spent time inside the mall, shopping and socializing, it became the place that symbolized the contradictions produced by the imperative of consumerism. The consumption promoted by the stores conflicted with the economic conditions of the families under the burden of mortgage payments. This 'financial misfit' was intensified by the 'cultural misfit' between the 'proper' use of the mall and the residents' previous experiences in the gecekondu.

\section{Conclusion}

This article has engaged with the 'new social' that emerged in a gecekondu rehousing project, which came in hybrid forms and contested ways. This new social was the product of the contradicting responses of residents to a planned environment that radically differed from their previous environment of informality. The abstract space of the built environment was the embodiment of the discourse of development and the political economy of neoliberalism. In the use of standard apartment plans originally designed for middle-classes, and the construction of high-rise apartment blocks in a distant location from the city centre, the abstract space of K-TOKI was the product of an approach that devalued residents' previous experiences in the gecekondu and undermined the idea of designing the estate to respond to their needs and preferences. Promising them upward social mobility via the representation of the apartment as the place of urban middle-classes, it carried the potential to erode the community-centred lives of the gecekondu, and promising them homeownership on the condition that they paid mortgage loans, it again carried the potential to transform social relations towards prioritizing individual interests over the community, as well as to create new subjectivities that embraced the idea of economic gains and individualistic lives. Some residents came more under the influence of the discourses of promise than others, striving towards achieving them. Remembering their experience of intimate and informal neighbourly relations in their recent past in the gecekondu, others were critical of the formalized neighbourly relations and privatized lives in their new housing estate. They actively transformed the housing estate to incorporate the 'old social,' reproducing their old habits and relations; through the informal production of space in a formal setting, they challenged the abstract space of authorities. Yet, it conflicted with other residents who internalized the middle-class way of life, stigmatizing their neighbours as ignorant people who could not adjust to apartment living. Thus, the move to apartments divided the former gecekondu community when some residents embraced the desire for social mobility and individualistic lives, while others carried the propensity to stick to their old way of life, opposing change. In the latter case, the support mechanisms in the gecekondu, both social and economic, were reproduced in small groups of neighbours in an environment whose design did not support such formation; the misfit between the built environment and women's 'gecekondu activities' came to characterize the estate. The absence of state regulation to a significant extent intensified the contestations, while it opened some space for some residents to challenge the imposed norms of 'proper behavior.' In sum, the production of the new social in this project was a contested process: those who did not want the new social that was imposed on them via the abstract space struggled with those who, in their 
appeal to apartment living, objected to the social space inserted by their neighbours into the abstract space of the housing estate. Thus, the socio-spatial conflicts and struggles in this residential environment were not limited to the tension between the social space of residents and the abstract space of authorities as theorized by Lefebvre; it extended to include the tension arising from the conflicting views and practices among residents regarding the 'proper use' of the abstract space.

In the new social taking shape in K-TOKI, Islam played a significant role. Actively organized in this housing estate, Islamic groups arranged religious activities such as Quran readings among women, opening new spaces of socialization in the unfamiliar environment of the estate and giving them material and emotional support. Such activities helped women to escape from everyday troubles, especially from the anxiety of failing to pay monthly mortgage instalments; they also brought the chance of making new acquaintances and becoming part of a social network that provided access to social assistance. This embracing of religion is not a personal matter; blending its neoliberal policies with its Islamist mission, AKP has created a habitus for the poor in which religion occupies the centre. ${ }^{12}$ Yet, through the insertion of Sunni Islam into everyday lives, Alevi residents experienced exclusion, the new social becoming an exclusionary development. Moreover, the shopping mall as the place of consumption-inspired everyday practices brought new challenges to residents: to perform their new role of mall users, they needed to develop a certain level of competence in the perceived space in Lefebvrian terms, and in their new role of mall customers, they needed to cope with the misfit between the urge to consume and their limited budget burdened by mortgage payments. They ended up being labelled as 'deficient customers', both in economic and cultural terms.

This article makes its contributions to the literature on urban renewal projects by demonstrating the contested nature of the new social in a gecekondu rehousing project, which is the product of the encounter of the top-down production of space by authorities and the bottom-up responses of residents. This new social is tied both to the political economy of neoliberalism and the rising Islam in the Turkish context. In the financialization of the transformation of informal housing, the promotion of individualization, and the injection of consumerism, neoliberalism provides the common ground for the new social in urban renewal projects in different countries. Yet, Islam's position in the new social is specific to Turkey: distancing itself from any responsibility to support people in their new lives in the housing estate, the state has left it wide open to Islamist influence. To enhance our understanding of the outcomes of urban renewal projects, we need to focus on the 'new social' in diverse contexts. I argue that when triggered by a top-down approach and implemented by a profit-oriented logic, they bring more harm to the dwellers of informal housing than benefit, destroying their communities and creating contested social relations.

\section{Notes}

1. Other terms used in the literature for urban renewal projects are 'slum upgrading,' 'slum improvement,' 'slum/urban redevelopment' and 'slum rehabilitation.' For the Turkish case, the term 'urban transformation project' is used, in which 'gecekondu transformation project' is a subset.

2. 'Informal housing' originally refers to unplanned settlements in which owners lack legal land documents and/or houses defy building codes. Over the years, it showed variations in terms of land tenure and the quality of houses. In the article, 'squatter housing' is used interchangeably 
with 'informal housing.' In the literature, the term 'slum' has been increasingly used to refer to such developments in the global South, which may be inappropriate for various reasons (Gilbert, 2007).

3. Yet, this idea failed due to the difficulties in the bidding process of the 'financial housing.'

4. The discussion of the shopping mall partially dwells upon the field research conducted in my guidance during the graduate course 'Qualitative Research Methods' in the spring semesters of 2016 and 2017. I thank my students for their contributions.

5. This may be because I did not ask a direct question on this issue.

6. In the questionnaire, $82 \%$ said that, although it would be difficult, they would pay their mortgage loans.

7. In the national elections of 2011,89\% voted for the AKP.

8. AKP (Adalet ve Kalkınma Partisi) is called 'AK Party' by the party's cadre ('AK' meaning 'white' in Turkish); by flashing out the word 'AK', they represent the party with this word's associated meanings.

9. Zikir is religious ceremony in which participants go into trance by hymning the word ' $h u$ ' and moving their bodies back and forth.

10. The influence of Islamic groups on children and youth is an important subject, which is beyond the scope of this article.

11. Alevism is a heterodox sect that has features from Shamanism, Judaism, Christianity and Islam (syncretic tradition). Alevis distinguish themselves from Sunni Muslims in various ways including not practicing sex-segregation and women's hijab. Alevis are devout followers of secularism of the early Republic, and they pride themselves on gender equality (see White \& Jongerden, 2003 for more information on Alevism).

12. This is also true for the 'new middle class' who have become more devoted to Islam as they have increased their affluence via the support and economic policies of the AKP.

\section{Disclosure statement}

No potential conflict of interest was reported by the author.

\section{Funding}

This work was supported by the TUBITAK (The Scientific and Technological Research Council of Turkey) [project number 109K360].

\section{Notes on contributor}

Tahire Erman is associate professor at Bilkent University, Department of Political Science and Public Administration, Ankara, Turkey. Her main research interests include politics of place; urban informality and its recent formalization; neoliberal urbanism; housing of disadvantaged groups; place-making; gender issues; and migration/mobilities. She published in such journals as International Journal of Urban and Regional Research; Urban Studies; Environment and Planning A; Environment and Behavior; Habitat International; Gender, Place and Culture; Gender \& Society; Women's Studies International Forum; and Urban Anthropology.

\section{References}

Ayata, S. (1989) Toplumsal çevre olarak gecekondu ve apartman [The gecekondu and the apartment as social environment], Toplum ve Bilim, (46/47), pp. 101-127.

Bartu-Candan, A. \& Kolluoğlu, B. (2008) Emerging spaces of neoliberalism: A gated community and a public housing project in Istanbul, New Perspectives on Turkey, 39, pp. 5-46. 
Buğra, A. \& Keyder, Ç. (2006) The Turkish welfare regime in transformation, Journal of European Social Policy, 16(3), pp. 211-228.

Danielson, M. N. \& Keleş, R. (1985) The Politics of Rapid Urbanization (New York and London: Holmes and Meier).

Doshi, S. (2013) The politics of the evicted: Redevelopment, subjectivity, and difference in Mumbai's slum frontier, Antipode, 45(4), pp. 844-865.

Erman, T. (1996) Women and the housing environment: The experiences of Turkish migrant women in squatter (gecekondu) and apartment housing, Environment and Behavior, 28(6), pp. 764-798.

Erman, T. (1997) The meaning of city living for rural migrant women and their role in migration: The case of Turkey, Women's Studies International Forum, 20(2), pp. 263-273.

Erman, T. (1998) The impact of migration on Turkish rural women: Four emergent cases. Gender \& Society, 12(2), pp. 146-167.

Erman, T. (2011) Understanding the experiences of the politics of urbanization in two gecekondu (squatter) neighbourhoods under two urban regimes: Ethnography in the urban periphery of Ankara, Turkey, Urban Anthropology, 40(1-2), pp. 67-108.

Erman, T. (2014) Migrant governmentality and integration in the neoliberal context: TOKI housing estates in the Northern Ankara Entrance and Istanbul Ayazma-Tepeüstü urban transformation projects, in: A. İçduygu \& Z. G. Göker (Eds) Rethinking Migration and Incorporation in the Context of Transnationalism and Neoliberalism, pp. 227-275 (Istanbul: Isis).

Erman, T. (2016) Formalization by the state, re-informalization by the people: A gecekondu (squatter) transformation housing estate as the site of multiple discrepancies, International Journal of Urban and Regional Research, 40(2), pp. 425-440.

Erman, T. \& Hatiboğlu, B. (2017) Rendering responsible, provoking desire: Women and home in squatter/slum renewal projects in the Turkish context, Gender, Place and Culture, 24(9), pp. $1283-1302$.

Fried, M. (1963) Grieving for a lost home, in: L. J. Duhl (Ed) The Urban Condition, pp. 151-171 (New York: Basic Books).

Ghannam, F. (2002) Remaking the Modern: Space, Relocation, and the Politics of Identity in a Global Cairo. (Berkeley: University of California Press).

Gilbert, A. (2007) The return of the slum: Does language matter?, International Journal of Urban and Regional Research, 31(4), pp. 697-713.

Harvey, D. (2003) The New Imperialism. (Oxford: Oxford University Press).

Harvey, D. (2005) A Brief History of Neoliberalism. (Oxford: Oxford University Press).

Jones, B. G. (2012) 'Bankable slums': The global politics of slum upgrading, Third World Quarterly, 33(5), pp. 769-789.

Karaman, O. (2008) Urban pulse - (re)making space for globalization in Istanbul, Urban Geography, 29(6), pp. 518-525.

Karaman, O. (2013) Urban neoliberalism with Islamic characteristics, Urban Studies, 50(6), pp. 1097-1113.

Keyder, Ç. (2000) Liberalization from above and the future of the informal sector: Land, shelter, and informality in the priphery, in: F. Tabak \& M. A. Crichlow (Eds) Informalization: Process and Structure, pp. 119-132 (Baltimore, MD: The Johns Hopkins University Press).

Kıray, M. (1979) Apartmanlaşma ve modern orta tabakalar [Apartmentalization and the modern urban strata], Çevre, 4, p. 78.

Koster, M. \& Nuijten, M. (2012) From preamble to post-project frustrations: The shaping of a slum upgrading project in Recife, Brazil, Antipode, 44(1), pp. 175-196.

Kuyucu, T. \& Ünsal, Ö. (2010) ‘Urban transformation' as state-led property transfer: An analysis of two cases of urban renewal in Istanbul, Urban Studies, 47(7), pp. 1479-1499.

Layton, L. (2014) Grandiosity, neoliberalism, and neoconservatism, Psychoanalytic Inquiry: A Topical Journal for Mental Health Professionals, 34, pp. 463-474.

Lefebvre, H. (1991) The Production of Space, Donald Nicholson Smith (trans). (Oxford: Blackwell). Lelandais, G. E. (2014) Space and identity in resistance against neoliberal urban planning in Turkey, International Journal of Urban and Regional Research, 38(5), pp. 1785-1806. 
Mangin, W. (1970) Peasants in Cities: Readings in the Anthropology of Urbanization. (Boston, MA: Houghton Mifflin).

Manzo, L. C., Kleit, R. G. \& Couch, D. (2008) 'Moving three times is like having your house on fire once': The experience of place and impending displacement among public housing residents, Urban Studies, 45(9), pp. 1855-1878.

Mukhija, V. (2003) Squatters as Developers: Slum Demolition and Redevelopment in Mumbai, India. (Hampshire: Ashgate).

Neuwirth, R. (2006) Shadow Cities: A Billion Squatters, a New Urban World. (New York: Routledge). Newman, O. (1972) Defensible Space: Crime Prevention through Urban Design. (London: MacMillan). Nijman, J. (2008) Against the odds: Slum rehabilitation in neoliberal Mumbai, Cities, 25(2), pp. 73-85. Pugh, C. (2000) Squatter settlements: Their sustainability, architectural contributions, and socioeconomic roles, Cities, 17(5), pp. 325-337.

Roy, A. (2009) Civic governmentality: The politics of inclusion in Beirut and Mumbai, Antipode, 41(1), pp. 159-179.

Salcedo, R. (2010) The last slum: Moving from illegal settlements to subsidized home ownership in Chile, Urban Affairs Review, 46(1), pp. 90-118.

Seufert, G. (1997) Between religion and ethnicity: A Kurdish-Alevi tribe in globalizing Istanbul, in: A. Öncü \& P. Weyland (Eds) Space, Culture and Power: New Identities in Globalizing Cities, pp.157-176 (London: Zed).

Shamir, R. (2008) The age of responsibilization: On market-embedded morality, Economy and Society, 37(1), pp. 1-19.

Smith, N. (1987) Gentrification and the rent gap, Annals of the Association of American Geographers, 77(3), pp. 462-465.

Suzuki, P. (1964) Encounters with Istanbul: Urban peasants and village peasants, International Journal of Comparative Sociology, 5, pp. 208-216.

Tuğal, C. (2009) The urban dynamism of Islamic hegemony: Absorbing squatter creativity in Istanbul, Comparative Studies of South Asia, Africa and the Middle East, 29(3), pp. 421-431.

Turner, J. F. C. (1976) Housing by People: Towards Autonomy in Building Environments. (London: Marion Boyars).

White, P. J. \& Jongerden, J. (2003) Turkey's Alevi Enigma: A Comprehensive Overview (Leiden and Boston: Brill). 